\title{
KONSTRUKTYWISTYCZNY SZACUNEK DO NAUKI. O PODEJŚCIU RICHARdA RORTY'Ego I BRUNO LATOURA
}

\author{
- Tomasz Szymon Markiewka -
}

\begin{abstract}
Abstrakt: Celem artykułu jest odpowiedź na pytanie: jak można być konstruktywistą, a jednocześnie traktować naukę jako jedno z najważniejszych osiągnięć współczesnych społeczeństw? Jako że konstruktywizm jest bogatym nurtem, mającym wiele odmian, autor skupia się tylko na jego dwóch przedstawicielach - Richardzie Rortym i Bruno Latourze. Stara się dowieść, że z połączenia wybranych aspektów ich stanowisk można zbudować spójną odpowiedź na zadane pytanie. Choć Rorty i Latour odrzucają realistyczną wizję nauki, to jednocześnie przekonują, że nauka jest skutecznym sposobem na radzenie sobie ze światem, czy też - by użyć terminu Latoura - z czynnikami pozaludzkimi. Tak więc to pragmatyczna kategoria "radzenia sobie” - a nie filozoficznie rozumiane pojęcia reprezentacji bądź korespondencji - staje się uzasadnieniem renomy nauki. Obaj myśliciele podkreślają, że skuteczność we wchodzeniu w interakcje z czynnikami pozaludzkimi jest wynikiem swoistej kultury współpracy i wzajemnej kontroli, wpisanej w działalność naukową.

Słowa kluczowe: konstruktywizm, nauka, Richard Rorty, Bruno Latour, teoria aktora-sieci, neopragmatyzm.
\end{abstract}

Published online: 19 June 2019

\section{Wprowadzenie}

Konstruktywizm jest jednym z tych nurtów filozoficznych, których domniemaną niedorzeczność próbowano wielokrotnie wykazać za pomocą krótkich eksperymentów myślowych. Na przykład Alan Sokal proponował żartobliwie, aby zwolennicy tego stanowiska wyskoczyli z okna sprawdzić, czy grawitacja jest tylko konstruktem społecznym $^{1}$. Podobnym przykładem posłużył się Richard Dawkins ${ }^{2}$. Takie ironiczne propozycje są na porządku dziennym. Prawdopodobnie jedynym nurtem, którego tezy starano się obalić równie często przy użyciu tego rodzaju przykładów, jest idealizm. To zresztą nieprzypadkowa zbieżność, ponieważ konstruktywizm jest zazwyczaj traktowany przez jego przeciwników jako po prostu kolejna wersja idealizmu.

Tomasz Szymon Markiewka

Wydział Lekarski CM UMK

ul. Jagiellońska 13-15

85-067 Bydgoszcz

e-mail: markiewkatomasz@wp.pl

${ }^{1}$ Sokal (1996).

${ }^{2}$ Hacking (1999): 67. 
Choć próby obalenia tez konstruktywistycznych przybierają często humorystyczną formę, to obawy, które się za nimi kryją, są poważne. Jedną z nich jest przekonanie, że konstruktywizm, bezpośrednio lub pośrednio, prowadzi do zlekceważenia całego dorobku naukowego - że zrównuje naukę z, powiedzmy, astrologią, ponieważ jedną i drugą traktuje jako zaledwie wytwory społeczne, niemające odniesienia do rzeczywistości. Takie zarzuty stawiają np. Bricmont i Sokal w swojej słynnej książce o postmodernizmie ${ }^{3}$. W bardziej umiarkowanej wersji krytyka konstruktywizmu opiera się na przekonaniu, że przedstawiciele tego nurtu nie potrafią wyjaśnić zadawalająco, skąd bierze się sukces nauki - że w myśl ich poglądów należałoby uznać, iż skuteczność działalności naukowej jest czymś w rodzaju cudu

Te zarzuty i obawy doczekały się wielu odpowiedzi. Można je podzielić na trzy gatunki. Do pierwszego należą teksty próbujące wykazać, że krytycy danego stanowiska konstruktywistycznego nie zrozumieli, o co w nim chodzi, bezpodstawnie radykalizując jego tezy. Dobrymi przykładami takich ripost są artykuły Michela Callona ${ }^{5}$ i Barbary Tuchańskiej ${ }^{6}$ zawierające polemikę z zarzutami Sokala i Bricmonta skierowanymi wobec poglądów Bruno Latoura. Drugi gatunek to teksty ironiczne, które na zarzut o niedorzeczność konstruktywizmu odpowiadają analogicznym zarzutem o niedorzeczność krytyk tego nurtu. Tak na przykład postępuje Steven Shapin ${ }^{7}$. Do trzeciego gatunku zaliczam teksty wyjaśniające - nie bronią one konstruktywizmu wprost, lecz starają się uporządkować cały narosły wokół niego spór za pomocą wprowadzenia odpowiednich rozróżnień i definicji, niejako przy okazji dowodząc, że przynajmniej niektóre tezy konstruktywistyczne są sensowne. Klasycznym już przykładem tego rodzaju podejścia jest słynna książka Iana Hackinga The Social Construction of What? ${ }^{8}$.

Mój cel w tym artykule jest jeszcze inny. Nie chcę ani dowodzić, że autor danego tekstu źle interpretuje tezy konstruktywistyczne, ani odpowiadać złośliwościami na złośliwości, ani porządkować dyskusji między konstruktywistami i realistami. Pragnę natomiast przedstawić możliwie zwięzłą i prostą odpowiedź na obawę stojącą za wieloma zarzutami wobec konstruktywizmu - na lęk, że konstruktywizm prowadzi do pomniejszenia czy wręcz lekceważenia zdobyczy naukowych. Innymi słowy, chcę pokazać w sposób, który nie wymaga fachowej znajomości konstruktywizmu, dlaczego można być zwolennikiem tego nurtu, a jednocześnie szanować naukę i traktować ją jako jedno z najważniejszych osiągnięć współczesnych społeczeństw. Przez szacunek rozumiem branie na serio dokonań i twierdzeń naukowych. Traktowanie ich nie jako jednego z wielu możliwych punktów widzenia, lecz jako fachowej, eksperckiej wiedzy. Nie chodzi przy tym o bezkrytyczne akceptowanie każdego twierdzenia naukowego ani o forsowanie tezy, że nauka powinna być w dowolnych okolicznościach najważniejszym punktem odniesienia, gdy dyskutujemy o kształcie naszych społeczeństw. Szacunek,

\footnotetext{
3 „Drugim przedmiotem naszego ataku jest relatywizm poznawczy, a mianowicie teza, że nowoczesna nauka jest tylko «mitem», «narracją» lub «społeczną konstrukcją», jakich wiele” - Sokal, Bricmont (2004): 10

${ }^{4}$ Chodzi o tak zwany ,argument z cudu”. Jego sformułowanie zob. np. Putnam (1975): 73.

5 Callon (1999): 261-286.

6 Tuchańska (2006): 93-111.

7 Shapin (2001): 99-115.

${ }^{8}$ Hacking (1999).
} 
o którym piszę, oznacza raczej, że konsensus naukowy, np. w sprawie wpływu człowieka na globalne ocieplenie, nie powinien być traktowany na równi z opiniami osób, które nie mają kompetencji w tej dziedzinie. To, jakie polityczne bądź społeczne konsekwencje wyciągamy z tego rodzaju szacunku dla nauki, jest odrębną kwestią, której w tym tekście nie podejmuję.

Nieprzypadkowo piszę, że zależy mi na zrobieniu tego „w sposób, który nie wymaga fachowej znajomości konstruktywizmu". Każde stanowisko filozoficzne, którego ambicją jest wyjście poza ciasne ramy własnej specjalizacji i odgrywanie istotnej roli w społeczeństwie - a wielu konstruktywistów ma takie ambicje - musi umieć odpowiedzieć w zrozumiały sposób na podstawowe pytania o wymiarze społecznym, takie jak na przykład te związane z wizją nauki i jej rolą we współczesnym świecie. Istnieje wiele prac konstruktywistycznych, o których można z przekonaniem powiedzieć, że obalają przekonanie, jakoby konstruktywiści nie szanowali nauki. Zalicza się do nich choćby wydana niedawno książka Czyje lęki? Czyja nauka? Struktury wiedzy wobec kontrowersji naukowo-społecznych autorstwa Andrzeja W. Nowaka, Krzysztofa Abriszewskiego i Michała Wróblewskiego'. Niemniej jednak ich głównym celem nie jest udzielenie odpowiedzi na podstawowe wątpliwości związane ze stosunkiem konstruktywistów do nauki - poruszają ten temat, ale to nie on stoi w centrum zainteresowań autorów, którzy skupiają się na bardziej szczegółowych i specjalistycznych kwestiach.

Jeszcze jedna uwaga tytułem wstępu. Bardzo trudno jest mówić o konstruktywizmie jako jednolitym zjawisku. Nurt ten ma już co najmniej kilkadziesiąt lat i doczekał się wielu odmian. Istnieje niemiecka szkoła radykalnego konstruktywizmu, konstruktywizm neopragmatystyczny, mocny program socjologii wiedzy, niedualistyczny sposób myślenia reprezentowany przez Josepha Mitterera, poststrukturalizm, teoria aktora-sieci itd. Wszystkie te formacje różnią się między sobą w istotnych punktach, a w stosunku do części z nich istnieje dyskusja, na ile w ogóle są konstruktywistyczne ${ }^{10}$. Nie sposób sensownie pisać o wszystkich naraz, nawet gdybyśmy przeszli na bardzo ogólny poziom analizy. Dlatego w tym tekście skupiam się na poglądach dwóch przedstawicieli szeroko pojętego konstruktywizmu: Richardzie Rortym i Bruno Latourze. Czemu właśnie na nich? Uważam, że połączenie ich podstawowych tez zapewnia najprostszą, a jednocześnie spójną odpowiedź na wspomniane wcześniej lęki przeciwników konstruktywizmu11. Choć poglądy tych myślicieli miejscami znacząco się od siebie różnią - Rorty jest zdecydowanie bardziej teoriocentryczny niż Latour - to łączy ich to, że na poziomie podstawowych idei obaj proponują odpowiednie, z perspektywy powziętych w tym artykule celów, połączenie prostoty i uzasadnienia szacunku do nauki. Zdaję sobie jednocześnie sprawę z tego, że w przypadku zarówno Rorty'ego, jak i Latoura można zadać pytanie, w jakim stopniu ich poglądy są konstruktywistyczne. Pozwolę

\footnotetext{
${ }^{9}$ Nowak, Abriszewski, Wróblewski (2016).

${ }^{10}$ Krótkie omówienie różnych odmian konstruktywizmu zob. np. Bińczyk (2015): 209-212.

${ }^{11}$ Nie twierdzę przy tym, że - wzięte całościowo - poglądy Latoura i Rorty’ego układają się w spójną całość. Choć Rorty wyrażał się bardzo pochlebnie o stanowisku francuskiego socjologa, to istnieją między nimi znaczące różnice. Chodzi mi jedynie o to, że w odniesieniu do konkretnego celu, mianowicie: udowodnienia, że można być konstruktywistą i szanować naukę - da się połączyć poglądy obu myślicieli, tak aby stworzyć $\mathrm{z}$ nich koherentne stanowisko.
} 
sobie na razie zawiesić tę wątpliwość, aby powrócić do niej w ostatniej części tekstu. W tym miejscu niech wystarczy stwierdzenie, że obaj w różnych okresach swojej działalności używali nazwy „konstruktywizm” do samookreślenia się ${ }^{12}$ - i w taki też sposób ich poglądy były nazywane przez przynajmniej część badaczy.

\section{Rorty - skuteczność nauki}

Zacznijmy od Rorty'ego, ponieważ - jak postaram się dowieść - w jego poglądach znajdziemy idee, które stanowią dobrą podstawę dla konstruktywistycznego wyjaśnienia, dlaczego nauka jest godnym szacunku i skutecznym przedsięwzięciem. Oprócz tego aspektu pozytywnego podejście amerykańskiego filozofa zawiera również aspekt negatywny, polegający na odrzuceniu błędnych w jego mniemaniu koncepcji pronaukowych. Wykorzystam ten krytyczny rys jako punkt wyjścia do zrozumienia stanowiska Rorty'ego. Odkładam jednocześnie na bok pytanie, czy istnieją filozofowie wyznający stanowisko poddawane przez niego krytyce, czy też może autor Konsekwencji pragmatyzmu wymyśla sobie przeciwnika. W tej chwili moim celem nie jest ocenianie, na ile zarzuty Rorty'ego wobec oponentów są słuszne, lecz zrozumienie jego własnego podejścia.

Na pytanie, dlaczego działalność naukowa ma tak dużą wartość dla współczesnych społeczeństw, Rorty odpowiada: na pewno nie z powodu tego, że naukowcy odkrywają wewnętrzną naturę rzeczywistości (intrinsic nature of reality). To sformułowanie - „wewnętrzna natura rzeczywistości” - wymaga doprecyzowania, ponieważ samo w sobie jest niejasne. Kiedy Rorty głosi, że nie istnieje coś takiego jak wewnętrzna natura rzeczywistości, to nie należy - jak robi to część badaczy ${ }^{13}$ - wyciągać z tego wniosku, że amerykański filozof odrzuca istnienie samej rzeczywistości. Nie ma on wątpliwości, że jest coś takiego jak świat materialny i że przedmioty, z którymi ludzie stykają się na co dzień, nie są wytworem naszej wyobraźni czy też innych procesów myślowych. Podkreślał to wielokrotnie. Dla przykładu spójrzmy na wybrane cytaty: „Antyesencjalista nie ma najmniejszych wątpliwości, że drzewa i gwiazdy istniały na długo przed pierwszymi sądami na ich temat"14, „[Pragmatysta] zgadza się, że istnieje coś takiego, jak ślepy opór materii - nacisk fal świetlnych na gałkę oczną Galileusza lub ucisk kamienia na but doktora Johnsona"15.

Skoro tak, to co właściwie odrzuca Rorty, gdy krytykuje pogląd o istnieniu wewnętrznej natury rzeczywistości? Mówiąc ogólnie, autor Konsekwencji pragmatyzmu wyraża głęboki sceptycyzm wobec tezy, że jest coś takiego jak Jeden Poprawny Opis Rzeczywistości albo Najwłaściwszy Opis Świata. Jego zdaniem żaden obszar naszej kultury, wliczając w to wszelakie nauki, nie może sobie rościć prawa do tego, że znalazł jedynie

\footnotetext{
${ }^{12}$ Choć obydwaj zachowywali wobec niej dystans. Na przykład Latour najpierw używał nazwy „konstruktywizm społeczny”, ale szybko uznał ją za mylącą, więc ograniczył się do samego „konstruktywizmu” (wykreślając przymiotnik „,społeczny”), później zaś zaproponował, aby określać jego poglądy mianem „kompozycjonizmu”. Zob. Latour (2010).

${ }^{13}$ Np. Buczyńska-Garewicz (2008). Polemika z jej krytyką zob. Markiewka (2014).

${ }^{14}$ Rorty (2013): 109.

${ }^{15}$ Rorty (1999): 123.
} 
słuszny sposób na opisanie właściwości świata lub radzenia sobie z nim ${ }^{16}$. Nie znaczy to, że wszystkie opisy czy sposoby postępowania są tak samo dobre (lub tak samo złe). Ten rodzaj relatywizmu Rorty również odrzuca, twierdząc że - po pierwsze - nikt nie jest w stanie konsekwentnie i poważnie być tego typu relatywistą (każdy z nas uważa, że pewne poglądy są lepsze, a inne gorsze) oraz - po drugie - że jest to pogląd wewnętrznie sprzeczny (teza, że żaden pogląd nie jest lepszy od innych, musi obejmować samą siebie, a więc samą siebie podważać) ${ }^{17}$. W opinii Rorty'ego istnieją lepsze bądź gorsze sposoby opisywania i radzenia sobie z rzeczywistością, ale ich ocena zawsze jest uzależniona od celu, jaki sobie - my, ludzie - stawiamy.

Wszystkie takie cele są równouprawnione z filozoficznego punktu widzenia, w odróżnieniu od perspektywy praktycznej. Nie istnieje żaden nadrzędny i pierwszorzędny cel zwany „odkryciem prawdy”. Jak stwierdziłem wcześniej, pragmatyści nie sądzą, jakoby prawda stanowiła cel dociekań. [...] istnieje tyle różnych narzędzi, ile celów, których realizacji mają służyć ${ }^{18}$.

Nigdy nie mówimy o rzeczywistości czy jej właściwościach samych w sobie zawsze są to właściwości widziane z perspektywy określonego gatunku, jego obecnego stanu wiedzy i potrzeb.

Posłużmy się obrazową, choć rzecz jasna uproszczoną i niedoskonałą analogią. Jeśli naszym celem jest przybicie gwoździa, to z pewnością młotek nadaje się do tego lepiej niż kostka masła ${ }^{19}$. Relatywizowanie tej skuteczności nie miałoby sensu. Zarówno młotek, jak i gwóźdź posiadają właściwości materialne, które sprawiają, że mogą one wejść w skuteczną interakcję, gdy naszym celem jest wbicie tego drugiego. Nie znaczy to jednak, że młotek lepiej reprezentuje gwóźdź, lepiej oddaje jego wewnętrzna naturę bądź lepiej wyjawia prawdę na jego temat niż kostka masła. Rorty proponuje, aby w mniej więcej ten sam sposób myśleć o nauce: nie jako sposobie na reprezentowanie prawdy bądź wewnętrznej natury, lecz jako czymś, co pozwala nam wchodzić w udane interakcje ze światem materialnym. Przez „udane interakcje” Rorty rozumie przede wszystkim kontrolowanie i przewidywanie zjawisk fizycznych ${ }^{20}$.

Amerykański filozof uważa takie podejście za darwinowskie ${ }^{21}$. Jego zdaniem rozwój nauki to nie tyle rozwój naszych umiejętności docierania do natury rzeczy, co raczej postęp $\mathrm{w}$ radzeniu sobie $\mathrm{z}$ otaczającym nas środowiskiem. Stąd zamiast słów takich jak "prawda”, ,wewnętrzna natura rzeczywistości”, ,reprezentowanie”, ,odzwierciedlanie" czy "korespondowanie”, które Rorty utożsamia z tradycją realistyczną w filozofii, preferuje on słownik składający się z wyrazów i sformułowań w rodzaju "skuteczne", „nadające się do określonego celu”, "praktyczne” czy "pożyteczne”.

\footnotetext{
16 Więcej na ten temat zob. Szubka (2012): 117-138.

17 Rorty (1998a): 213.

${ }^{18}$ Rorty (2013): 104-105.

${ }^{19}$ Nawiązuję do przykładu, który pojawił się w dyskusji między Andrzejem Szahajem i Wojciechem Kalagą.

Zob. Szahaj (2014): 56, Kalaga (1997): 88.

${ }^{20}$ Rorty (1999): 55-69.

${ }^{21}$ Rorty (2013): 115-116.
} 
Rorty nie twierdzi przy tym, że powinniśmy wykreślić słowa takie jak „prawda” z codziennego użytku²2. Podobnie ma się sprawa z pojęciem „reprezentacji”. Nie neguje on na przykład tego, że mapa reprezentuje jakiś kawałek przestrzeni - w tym banalnym sensie, że pomaga się po nim poruszać (a więc pełni funkcję praktyczną). Powiedziałby po prostu, że istnieje zasadnicza różnica między tego typu reprezentacją a taką, której zadaniem jest zapewnianie Ostatecznego bądź Jedynie Słusznego Opisu Świata. Mapa Warszawy nie daje nam reprezentacji tego miasta w takim mocnym, filozoficznym znaczeniu, a jedynie $\mathrm{w}$ konwencjonalny sposób przedstawia wybrane aspekty stolicy tak, aby ułatwić poruszanie się po niej.

Rorty podkreśla, że gdy filozofowie zaczynają mówić o nauce, jej wartości i autorytecie, to kategorie prawdy, korespondencji czy niezależnej od naszych czynności poznawczych rzeczywistości są zbędne. Widać to na przykład w jego polemice z Johnem Searlem na temat postmodernizmu. Searle uważa, że popularni filozofowie francuscy w rodzaju Jacques'a Derridy szkodzą działalności naukowej przez swój nonszalancki stosunek do prawdy czy rzeczywistości. W opinii Rorty'ego nie ma to większego znaczenia, ponieważ wcale nie potrzebujemy określonej filozoficznej perspektywy odnoszącej się do wymienionych kategorii. Znaczące jest to, w jaki sposób Rorty próbuje odebrać filozoficzną doniosłość kategorii „reprezentacji”, gdy w tekście o Searle'u opisuje pracę historyków.

Kiedy mówimy, że dobrzy historycy trafnie reprezentują to, co znaleźli w archiwach, mamy na myśli tyle, że włożyli wiele wysiłku w poszukiwanie odpowiednich dokumentów, że nie zlekceważyli tekstów przeczących wysuwanym przez nich tezom, że nie cytowali w mylący sposób fragmentów wyrwanych z kontekstu, że mówią nam to samo, co głoszą między sobą, i tak dalej. Przyjęcie, że historyczka wiernie oddaje fakty, które zna, to przyjęcie, że przestrzega ona sposobu postępowania dobrego, uczciwego przedstawiciela jej dyscypliny. Nie zakładamy niczego na temat realności przeszłych zdarzeń - ani ich warunków prawdziwości, ani z konieczności hermeneutycznego charakteru Geisteswissenschaften, ani żadnego innego zagadnienia filozoficznego ${ }^{23}$.

Dotykamy tu następnego ważnego aspektu podejścia Rorty'ego do nauki. Amerykański filozof twierdzi, że naukowcy tak dobrze radzą sobie ze stawianymi im zadaniami, ponieważ wytworzyli środowisko sprzyjające rzetelnej pracy. Bywa ono dalekie od ideału, ale i tak stanowi w naszej kulturze jeden z najlepszych, jeśli po prostu nie najlepszy przykład rozstrzygania sporów przez wymianę argumentów, a nie stosowanie przemocy. Jak pisze Rorty:

[...] przyrodoznawcy służą za dobry przykład społecznej współpracy - kultury eksperckiej, w której kwitnie argumentacja. Proponują oni w ten sposób pewien model dyskusji politycznej - model oparty na uczciwości, tolerancji i zaufaniu. Ta

\footnotetext{
${ }^{22}$ Rorty (1998b): 44-45.

${ }^{23}$ Rorty (1998b): 73.
} 
zdolność jest raczej sprawą procedury niż wyników i dlatego grupa cieśli lub zespoły inżynierów mogą dostarczyć nam model równie dobry jak ten, który proponuje Towarzystwo Królewskie ${ }^{24}$.

Rorty wypowiada się w podobnym duchu w artykule Nauka jako solidarność. Wyraża w nim przekonanie, że nie powinniśmy traktować naukowców jako współczesnych kapłanów - jako ludzi mających uprzywilejowany dostęp do prawdy i natury rzeczywistości. Wartość działalności naukowej polega głównie na jej skuteczności w osiąganiu ludzkich zamierzeń, ta zaś jest efektem swoistej kultury współpracy:

[...] cnoty, jakie posiadają naukowcy, to nawykowe poleganie raczej na perswazji niż na sile, szacunek dla opinii kolegów, zapał i ciekawość dla nowych danych i nowych idei. [...] W tej perspektywie nie ma powodu, by wychwalać naukowców, że są bardziej „obiektywni”, „logiczni”, „metodyczni” czy oddani prawdzie niż inni. Istnieje jednak wiele powodów, by chwalić instytucje, jakie stworzyli i w których pracują, i by traktować je jako modelowe rozwiązanie dla pozostałych dziedzin kultury. Owe instytucje bowiem konkretyzują i dookreślają ideę „niewymuszonego porozumienia”"25.

Jest to typowa dla Rorty'ego próba upragmatycznienia, uspołecznienia i ściągnięcia na ziemię filozoficznego podejścia do nauki. Na pytanie: „Czy uważasz, że powinniśmy traktować opinie klimatologów na temat globalnego ocieplenia poważniej niż poglądy laików, a jeśli tak, to dlaczego?” Rorty odpowiedziałby coś w rodzaju: „Tak właśnie uważam. Z dwóch powodów. Po pierwsze, naukowcy wielokrotnie dowodzili, że potrafią trafnie przewidywać i do pewnego stopnia kontrolować różne zjawiska, $\mathrm{w}$ tym te związane z klimatem. Innymi słowy, są dobrzy w odpowiadaniu na nasze, ludzkie zapotrzebowania. Po drugie, działają w społeczności zapewniającej, że możemy ufać ich rzetelności i uczciwości". Amerykański filozof unikałby za wszelką cenę filozoficznych odniesień do prawdy, rzeczywistości czy korespondencji między teorią a światem - do czegoś, co Hacking nazywa "słowami windującymi" 26.

Trudno rzecz jasna uznać stanowisko Rorty'ego za odporne na zarzuty. U podstaw jego przekonania leży argument, że realistyczne podejście do prawdy i tym podobnych kategorii najzwyczajniej w świecie nie jest potrzebne do prowadzenia działalności naukowej ani do zapewnienia nauce należytego miejsca w naszych społeczeństwach. Można to łatwo odeprzeć: „Nawet jeśli masz rację, to wcale nie oznacza, że realizm jest błędnym stanowiskiem lub niewartym rozwijania. Bycie lub niebycie koniecznym do prowadzenia działalności naukowej nie jest bowiem kryterium rozstrzygającym o wartości jakiegokolwiek stanowiska filozoficznego". Jest to sensowny zarzut wobec podejścia Rorty'ego, ale o tyle nieważny w tym tekście, że nie rozważam tutaj, czy amerykański filozof wygrał bitwę argumentacyjną ze swoimi oponentami. Interesuje mnie jedynie to, czy Rorty potrafi wytłumaczyć na gruncie przyjętych przez siebie założeń, skąd bierze się jego szacunek do działalności naukowej.

\footnotetext{
${ }^{24}$ Rorty (2009a): 164.

25 Rorty (1999): 61.

${ }^{26}$ Hacking (1999): 22-24. Zob. też tłumaczenie tego fragmentu książki w: Hacking (2015): 40-42.
} 


\section{Latour - poza język}

Nie ulega jednak wątpliwości, że nawet jeśli skupimy się tylko na stosunku Rorty'ego do nauki, znajdziemy w jego stanowisku istotne braki. Amerykański filozof ogranicza się do aspektu językowo-symbolicznego działalności naukowej: stąd tyle mówi o opisach i teoriach. Czasami prowadzi go to na manowce. Na przykład wtedy, gdy zaczyna mówić, że cały język jest metaforyczny, a metafory można porównywać jedynie z innymi metaforami ${ }^{27}$. W takich momentach Rorty zupełnie gubi zarówno czynnik materialny, jak i praktyczną złożoność poznawania świata, zachowując się jak stereotypowy postmodernista. Zresztą sam był gotów przyznać, że miał skłonność do popadania w przesadę $\mathrm{w}$ tego rodzaju kwestiach ${ }^{28}$. Dlatego dobrze jest uzupełnić podstawowe idee Rorty'ego na temat nauki poglądami Latoura, któremu można zarzucać różne rzeczy, ale z pewnością nie lekceważenie czynników pozajęzykowych.

Zacznijmy jednak od pokazania, że Latour zgodziłby się z wyłożonymi wcześniej podstawowymi tezami Rorty'ego na temat skuteczności nauki. Przede wszystkim nie ma wątpliwości, że francuski myśliciel również wyraża głęboki sceptycyzm wobec idei reprezentowania rzeczywistości. Widać to choćby w następującym fragmencie Nadziei Pandory:

Całe to stare pytanie o korespondencję między słowami a światem wyrasta z prostego pomieszania epistemologii z historią sztuki. Potraktowaliśmy naukę jako malarstwo realistyczne, wyobrażając sobie, że robi ona dokładną kopię świata. Jednakże nauki czynią coś zupełnie innego - nawiasem mówiąc, podobnie jak obrazy. Przez następujące po sobie etapy, łączą nas z uregulowanym, przekształconym i skonstruowanym światem ${ }^{29}$.

Tego rodzaju wypowiedzi muszą irytować zwolenników szeroko pojętego realizmu, ponieważ Latour za pomocą prostego porównania stara się zdeprecjonować jedno z głównych stanowisk w długim i skomplikowanym sporze filozoficznym. Gdybyśmy zastanawiali się nad tym, czy należy odrzucić realizm bądź ideę reprezentacji rzeczywistości, to takie cytaty jak ten powyżej byłyby dalece niewystarczające ${ }^{30}$. Podobnie jednak jak w przypadku Rorty'ego, chodzi mi przede wszystkim o pokazanie, w jaki sposób prezentuje się stanowisko samego Latoura, a nie o analizowanie, czy jego opis poglądów przeciwników jest zadowalający. Przytoczony fragment dowodzi, że Latourowi równie daleko jak Rorty'emu do polegania na słowach i sformułowaniach w rodzaju „korespondencja”, ,reprezentowanie” czy „niezależna od człowieka natura rzeczywistości”.

Latour wielokrotnie podkreślał też, że główną zaletą działalności naukowej jest jej skuteczność, która nie wynika z tego, że naukowcy odkrywają istotę rzeczywistości czy ostateczną prawdę, lecz z tego, że ludzie nauki potrafią wchodzić w interakcje

\footnotetext{
27 Rorty (2009b): 46.

28 Brandom (2008): 371-377.

${ }^{29}$ Latour (2013a): 112

30 Zresztą, żeby być sprawiedliwym wobec francuskiego socjologa, Latour w pierwszej części cytowanej książki podaje bardziej merytoryczne przesłanki na rzecz swojej tezy, ale nie sposób ich streścić w kilku zdaniach, stąd ograniczam się do zamieszczonego cytatu.
} 
z czynnikami pozaludzkimi (więcej o nich za chwilę) i budować dzięki ich wykorzystaniu trwałe sieci powiązań społecznych. Francuski socjolog pisze w Nadziei Pandory, że „im bardziej nauka podłączona jest do reszty zbiorowości, tym jest lepsza, bardziej ścisła, bardziej weryfikowalna i solidniejsza" ${ }^{31}$.

Podobnie jak Rorty, Latour myśli o nauce głównie w kategoriach radzenia sobie ze światem, a nie reprezentowania go - w kategoriach zbiorowej pracy i wzajemnej kontroli, a nie metody dochodzenia do Prawdy ${ }^{32}$. W jednej ze swoich ostatnich książek, An Inquiry Into Modes of Existence, francuski socjolog opisuje spotkanie klimatologa ze światem biznesu. Gdy jeden z przedsiębiorców pyta naukowca, dlaczego to jemu, a nie tzw. denialistom, mają wierzyć w kwestii globalnego ocieplenia, ten nie mówi o prawdzie, lecz o zaufaniu do instytucji nauki. Nie twierdzi, że naukowcy docierają do samej istoty rzeczy bądź natury świata, w ogóle nie odwołuje się do żadnej kategorii filozoficznej. Zamiast tego opowiada o ogromnej liczbie badań nad klimatem, o zaawansowanych narzędziach, za pomocą których się je prowadzi, o wzajemnej kontroli panującej w społeczności naukowej ${ }^{33}$. Latour uważa takie podejście za wysoce pożądane i jak łatwo dostrzec, łączy się ono z tym, co zaleca Rorty.

Sferą, w której Latour uzyskuje przewagą nad autorem Konsekwencji pragmatyzmu, jest praktyka naukowa. Francuski socjolog ma o wiele więcej do powiedzenia na temat tego, jak wygląda nauka w działaniu: w laboratorium lub w trakcie badań terenowych. Dzięki temu łatwiej niż Rorty unika pułapek związanych ze zbytnim skupianiem się na roli języka i opisu teoretycznego. Taka postawa znajduje wyraz w aparacie pojęciowym stosowanym przez Latoura. Warto zwrócić uwagę szczególnie na pojęcie aktora. W nurcie, w którym pracuje Latour, aktor to po prostu „ten, który działa” (lub „ta, która działa” czy też „to, które działa”) ${ }^{34}$. Wszystko, co dysponuje jakąś sprawczością, wszystko, co wpływa na ostateczny efekt danego procesu - jest aktorem. Może nim być człowiek, jego idee bądź język, którym się posługuje, ale równie dobrze za aktorów możemy uznać czynniki pozaludzkie, czyli na przykład drzewa, mosty, samochody, atomy czy gwiazdy.

Skupianie się na aktorach i definiowanie ich przez pryzmat sprawczości jest prostym ruchem, ale ma doniosłe konsekwencje. W podejściu Latoura nie ma już dwóch wielkich ontologicznych królestw: świata i języka (bądź w innej wersji: świata i umysłu). Jest pluralizm bytów, aktorów, wchodzących ze sobą w niezliczone interakcje. Człowiek jest tylko jednym z nich. Tym samym pojęcie aktora służy Latourowi do zarysowania własnego poglądu na rzeczywistość. Ta jego zdaniem składa się z aktorów właśnie - niczego więcej i niczego mniej. Innymi słowy, składnikiem rzeczywistości jest wszystko to, co dysponuje sprawczością, wszystko, co w jakiś sposób działa i zmienia innych aktorów. Niezależnie od tego, czy mówimy o atomach czy o Konstytucji Stanów Zjednoczonych. Dlatego mówi się, że ontologia Latoura jest płaska, nie różnicuje z góry aktorów ani pod

\footnotetext{
${ }^{31}$ Latour (2013a): 49.

${ }^{32}$ Choć należy dodać, że Latour pisze o funkcjonowaniu nauki o wiele szczegółowiej niż Rorty. Nie tylko w tym sensie, że przywiązuje większą wagę do praktyki naukowej, o czym piszę w tekście głównym, lecz także dlatego, że wprowadza więcej rozróżnień na poziomie teoretycznego opisu działania nauki. Na przykład w Nadziei Pandory wyróżnia pięć, jak je sam nazywa, pętli krążenia nauki: mobilizowanie świata, atomizacja, szukanie sprzymierzeńców, reprezentacja społeczna, powiązania i węzły. Latour (2013a): 113-148.

${ }^{33}$ Latour (2013b): 1-6.

${ }^{34}$ Abriszewski (2008): 10-11.
} 
względem ich realności, ani ważności. Nie oznacza to, że francuski socjolog nie dostrzega żadnych różnic między sposobem istnienia gwiazd a sposobem istnienia na przykład powieści. Chodzi o to, że nie dokonuje ogólnych, twardych rozróżnień „realnościowych” (szczególnie dualistycznych) w rodzaju tych, które proponuje na przykład John Searle: na rzeczywistość naturalną i rzeczywistość jedynie instytucjonalno-społeczną - na realność takich rzeczy jak drzewa (natura) i realność takich rzeczy jak pieniądze (społeczeństwo) ${ }^{35}$.

Podobnie jak w przypadku Rorty'ego, możemy nazwać to podejście darwinowskim - w tym sensie, że pytanie o reprezentację bądź korespondencję między językiem a rzeczywistością zostaje zastąpione pytaniem o skuteczność interakcji między ludźmi i czynnikami pozaludzkimi. Sukces nauki zdaniem Latoura bierze się stąd, że naukowcy są wyjątkowo dobrzy w "dogadywaniu się" z aktorami pozaludzkimi. Przewaga tego podejścia nad stanowiskiem amerykańskiego filozofa polega zaś na tym, że choć Rorty odrzucał pojęcia reprezentacji, korespondencji czy wewnętrznej natury rzeczywistości, to ciągle tkwił przy podziale na rzeczywistość i język, do którego te pojęcia odsyłają. W związku z czym od czasu do czasu wpadał w pułapkę filozoficznego faworyzowania jednego z członów tej alternatywy, twierdząc na przykład - o czym była już mowa - że metafory odsyłają tylko do innych metafor, że język odsyła sam do siebie. Co może być efektowną tezą filozoficzną, ale bardzo słabo oddaje to, jak wygląda praktyka naukowa, na przykład na etapie laboratoryjnym.

Latourowskie pojęcie aktora osłabia pokusę myślenia o nauce czy jakiejkolwiek ludzkiej działalności przez pryzmat dualistycznego podziału na świat i język, a tym samym pomaga konsekwentniej unikać opowiadania się po jednej ze stron (językowej bądź pozajęzykowej). Najlepiej widać to na przykładzie słynnej relacji Latoura z badań w Amazonii. Francuski socjolog zadaje sobie pytanie, w jaki sposób dokonuje się przeskok od dżungli amazońskiej do tekstu, który ją opisuje. Odpowiada, że żadnego przeskoku nie ma: jest za to długi ciąg przekształcen, interakcji i stanów pośrednich, w trakcie których aktorzy ludzcy i pozaludzcy nieustannie na siebie wpływają ${ }^{36}$. Poznanie nie jest kwestią adaequatio rei et intellectus, lecz umiejętnego łączenia ze sobą czynników ludzkich i pozaludzkich. Jeśli takie połączenie się uda - to znaczy, jeśli pozwala na skuteczne działanie - wtedy możemy mówić o korespondencji, ale jedynie w znaczeniu „,ta mapa dobrze odnosi się do określonego terenu, ponieważ pozwala się po nim skutecznie przemieszczać" ${ }^{\prime 2}$.

\section{Wnioski i wątpliwości}

Konstruktywistyczne podejście do nauki - w wersji omówionej w tym artykule - przedstawia się w największym skrócie następująco: (1) nauka nie odkrywa wewnętrznej natury rzeczywistości, nie dostarcza czegoś, co moglibyśmy nazwać "Jedynie Prawdziwym Opisem Świata", nie jest odpowiedzią na Platońskie pragnienie dotarcia do ostatecznej prawdy; (2) ma ona jednak inną, ogromną zaletę: pomaga nam wchodzić w skuteczne interakcje z czynnikami pozaludzkimi, pozwala przewidywać i do pewnego

\footnotetext{
35 Zob. Searle (1995).

${ }^{36}$ Latour (2013): 55-112. Zob. też Harman (2016): 118-129.

37 Zob. Latour (2013b): 69-95.
} 
stopnia kontrolować ich działanie, pozwala tworzyć z połączenia czynników ludzkich i pozaludzkich trwałe sieci powiązań, które przyczyniają się do rozwoju naszych społeczeństw (choć mogą też nieść zagrożenia); (3) jednym z najważniejszych powodów, dla których nauka tak dobrze sobie radzi z budowaniem wspomnianych sieci jest to, że wypracowaliśmy w jej ramach mechanizmy wzajemnej kontroli i współpracy - mechanizmy zbiorowego działania.

Takie wyjaśnienie konstruktywistycznego szacunku do nauki z pewnością budzi wiele pytań i wątpliwości. Nie sposób odnieść się do wszystkich, nie taki zresztą jest cel niniejszego tekstu. Niemniej jednak chcę pokrótce ustosunkować się do dwóch najważniejszych zarzutów, które można postawić przedstawionej przeze mnie mieszance wybranych poglądów Rorty'ego i Latoura.

Pierwsza wątpliwość dotyczy pytania, czy taka wersja filozofii konstruktywistycznej w ogóle jest jeszcze konstruktywizmem. Jak wspomniałem na początku tekstu, wiele osób traktuje ten nurt czy też kierunek jako odnogę idealizmu. Idealizm postrzega się zaś jako stanowisko, wedle którego świat materialny nie istnieje bądź też istnieje, ale jest podporządkowany działaniu umysłu, języka czy jakiejkolwiek innej kategorii związanej z czynnościami poznawczymi człowieka. Skoro zaś Rorty i Latour nie tylko uznają istnienie świata pozaludzkiego (od atomów, przez żyrafy, po dżungle), lecz dodatkowo przyznają mu sprawczość, to czy ich stanowisko nie jest czymś w rodzaju realizmu krytycznego? Problem polega na tym, że nie dysponujemy ścisłymi i powszechnie uznanymi definicjami rozstrzygającymi, jakie konkretnie warunki musi spełnić dane stanowisko, żeby zostać uznane za przejaw realizmu, idealizmu bądź konstruktywizmu. W tym sensie ten spór jest nierozstrzygalny. Wciąż możemy jednak podawać argumenty za lub przeciw klasyfikowaniu danych poglądów w określony sposób. Za zaliczeniem poglądów Rorty'ego i Latoura do konstruktywizmu przemawiają przede wszystkim dwie rzeczy. Po pierwsze, ich zdaniem na nasze postrzeganie tego, co Latour nazywa "czynnikami pozaludzkimi”, wpływają nie tylko one same, ale także my, z naszymi kategoriami poznawczymi i narzędziami, dzięki którym wchodzimy w interakcje ze światem - sprawczość jest zawsze po obu stronach, człowieczej i pozaczłowieczej. Po drugie, obaj myśliciele odrzucają aparat pojęciowy związany z realizmem. Starają się nie mówić o korespondencji, reprezentacji, naturze rzeczywistości czy świecie niezależnym od umysłu bądź języka. Zastępują te tradycyjne kategorie językiem pragmatycznym, skupiającym się na skuteczności, użyteczności czy też interakcjach. Nawet Graham Harman, który sugeruje, że można traktować poglądy Latoura jako odmianę realizmu relacyjnego, przyznaje, iż niedualistyczne tezy francuskiego myśliciela zrywają gwałtownie z tradycyjnymi założeniami realizmu ${ }^{38}$.

Druga wątpliwość dotycząca konstruktywistycznego podejścia do nauki jest związana z pytaniem, czy da się na dłuższa metę zrezygnować z pojęć takich jak korespondencja bądź reprezentacja. Wspominałem już na przykładzie mapy, że Rorty próbuje sobie poradzić z tym problemem przez odróżnienie codziennego, banalnego pożytku z pojęcia reprezentacji, od pożytku filozoficznego. $Z$ tym pierwszym nie ma problemu, podaje w wątpliwość tylko ten drugi pożytek. Nadal jednak pozostaje pytanie, czy

\footnotetext{
${ }^{38} \operatorname{Harman}(2016): 185$.
} 
w każdym przypadku da się sensownie przeprowadzić taki podział na niefilozoficzne i filozoficzne użycie danego pojęcia, a w konsekwencji, czy pragmatyczne kategorie w rodzaju „radzenia sobie z rzeczywistością bądź też czynnikami pozaludzkimi” są wystarczające, aby wytłumaczyć powodzenie każdego odcinka nauki. Dotykamy tutaj szerszego zagadnienia, które wiąże się z tym, że nauki i problemy naukowe są bardzo różne. W ich skład wchodzą zarówno dociekania nad narodzinami Wszechświata, jak i prace nad szczepionkami - zarówno praca teoretyczna, jak i laboratoryjna. Należy w związku z tym być ostrożnym, gdy idzie o wygłaszanie uniwersalistycznych twierdzeń na temat tego, jakie pojęcia są, a jakie nie są potrzebne do opisu nauki. Ta uwaga stosuje się jednak nie tylko do konstruktywizmu, lecz także do realizmu. Wielu badaczy, szczególnie socjologów nauki, zauważyło w ostatnich latach, że realistyczne podejście do działalności naukowej było zbyt teoriocentryczne i fizykocentryczne - że nie uwzględniało $\mathrm{w}$ dostatecznym stopniu zarówno pracy laboratoryjnej, jak i innych dziedzin nauki niż fizyka oraz dyscypliny pokrewne ${ }^{39}$. Dlatego też nie powinniśmy traktować kłopotów ze zuniwersalizowaniem danego stanowiska jako argumentu za jego odrzuceniem. Po prostu należy mieć na względzie ograniczenia wiążące się z daną wersją czy to konstruktywizmu, czy to realizmu.

Celem konstruktywizmu - przynajmniej w wersji Rorty'ego i Latoura - nie jest podważanie autorytetu nauki. Chodzi raczej o znalezienie innego niż tradycyjne uzasadnienia dla jej roli w społeczeństwie. Próba zmiany sposobu mówienia o danej rzeczy bądź zjawisku jest zawsze ryzykowna. Myśliciele konstruktywistyczni z pewnością nie unikają wszystkich pułapek, które wiążą się z tym ambitnym zadaniem. Warto i trzeba ich krytykować, gdy błądzą. Niemniej jednak nie ma sensu odmawiać im rozsądku bądź szacunku dla działalności naukowej. Trudno przecież mówić o tym, że dotychczasowe sposoby ujmowania nauki są niepodważalne i kompletne. Jak pisałem $\mathrm{w}$ poprzednim akapicie, podejście realistyczne skupiało się na wybranych aspektach pracy naukowej, głównie teoretycznych. W dodatku postęp techniczny, niosący nowe możliwości ingerowania w czynniki pozaludzkie, coraz bardziej komplikuje proste dualistyczne podziały na to, co naturalne i nienaturalne. Wszystko to sprawia, że filozofia nadal stoi przed poważnym zadaniem uchwycenia związków między nauką, polityką, społeczeństwem i przyrodą. Nowe języki, nowe podejścia, nowe sposoby myślenia mogą w tym znacząco pomóc.

\section{Bibliografia}

Abriszewski K. (2008), Poznanie, zbiorowość, polityka. Analiza teorii aktora-sieci Bruno Latoura, Universitas, Kraków.

Afeltowicz Ł. (2012), Modele, artefakty, kolektywy. Praktyka badawcza w perspektywie wspótczesnych studiów nad nauk, Wydawnictwo Naukowe UMK, Torun.

Bińczyk E. (2015), Postkonstruktywizm w badaniach nad nauka, [w:] Horyzonty konstruktywizmu. Inspiracje, perspektywy, przyszłość, E. Bińczyk, A. Derra, J. Grygieńć (red.), Wydawnictwo Naukowe UMK, Torun: 209-232.

Brandom R.B. (red.) (2008), Rorty and his Critics, Blackwell Publishing, Oxford.

Buczyńska-Garewicz H. (2008), Prawda i złudzenie. Eseje o myśleniu, Universitas, Kraków.

${ }^{39}$ Afeltowicz (2012): 13-17. 
Callon M. (1999), Whose Imposture? Physicists at War with the Third Person, "Social Studies of Science" 2 (29): 261-286.

Hacking I. (1999), The Social Construction of What?, Harvard University Press, Cambridge and London: 11-56.

Hacking I. (2015), Konstrukcja społeczna "czego"?, tłum. E. Bińczyk, [w:] Horyzonty konstruktywizmu. Inspiracje, perspektywy, przyszłość, E. Bińczyk, A. Derra, J. Grygieńć (red.), Wydawnictwo Naukowe UMK, Torun.

Harman G. (2016), Książe sieci. Bruno Latour i metafizyka, tłum. G. Czemiel, M. Rychter, Fundacja Augusta Hrabiego Cieszkowskiego, Warszawa.

Kalaga W. (1997), Tekst - wirtualność - interpretacja: w sprawie przybijania gwoździ, „Teksty Drugie" 6 (48): 83-92.

Latour B. (2010), An Attempt at a Compositionist Manifesto, [w:] „New Literary History” 41 (3): 471-490.

Latour B. (2013a), Nadzieja Pandory. Eseje o rzeczywistości w studiach nad nauka, tłum. K. Abriszewski et al., Wydawnictwo Naukowe UMK, Toruń.

Latour B. (2013b), An Inquiry into Modes of Existence. An Anthropology of the Moderns, Harvard University Press, Cambridge, Massachusetts, London, England.

Markiewka T.S. (2014), Rorty na temat prawdy i świata. Polemika z Hanna Buczyńska-Garewicz, „Diametros" 41: 152-167.

Nowak A.W., Abriszewski K., Wróblewski M. (2016), Czyje lęki? Czyja nauka? Struktury wiedzy wobec kontrowersji naukowo-społecznych, Wydawnictwo Naukowe UAM, Poznań.

Putnam H. (1975), Mathematics, Matter and Method, Cambridge University Press, Cambridge.

Rorty R. (1998a), Konsekwencje pragmatyzmu. Eseje z lat 1972-1980, tłum. Cz. Karkowski, IFiS PAN, Warszawa.

Rorty R. (1998b), Truth and Progress, Cambridge University Press, Cambridge.

Rorty R. (1999), Obiektywność, relatywizm i prawda, tłum. J. Margański, Aletheia, Warszawa.

Rorty R. (2009a), Filozofia jako polityka kulturalna, tłum. B. Baran, Spółdzielnia Wydawnicza Czytelnik, Warszawa.

Rorty R. (2009b), Przygodność, ironia i solidarność, tłum. W. J. Popowski, Wydawnictwo W.A.B, Warszawa.

Rorty R. (2013), Filozofii a nadzieja na lepsze społeczeństwo, tłum. J. Grygieńc, S. Tokariew, Wydawnictwo Naukowe UMK, Toruń.

Searle J.R. (1995), The Construction of Social Reality, Free Press, New York.

Shapin S. (2001), How to be Antiscientific, [w:] The One Culture? A Conversation About Science, J.A. Labinger, H. Collins, The University of Chicago Press, Chicago and London.

Sokal A. (1996), A Physicist Experiments With Cultural Studies, „Lingua Franca” May/June, URL = http:/ /linguafranca.mirror.theinfo.org/9605/sokal.html [dostęp 26.02.2018].

Sokal A., Bricmont J. (1998), Modne bzdury. O nadużywaniu pojęć z zakresu nauk ścistych przez postmodernistycznych intelektualistów, tłum. P. Amsterdamski, Prószyński i S-ka, Warszawa.

Szahaj A. (2014), O interpretacji, Universitas, Kraków.

Szubka T. (2012), Neopragmatyzm, Wydawnictwo Naukowe UMK, Torun.

Tuchańska B. (2006), O Sokalu z Bricmontem, Latourze i o tym, co z tego (nie) wynika, „Nauka” 1: 93-111. 